\title{
Adsorption of Aniline and Toluidines on Montmorillonite: Implications for the Disposal of Shale Oil Production Wastes
}

\section{Topical Report}

M.E. Essington

J.M. Bowen

R.A. Wills

B.K. Hart

January 1992

Work Performed Under Contract No.: DE-FC21-86MC11076

For

U.S. Department of Energy

Office of Fossil Energy

Morgantown Energy Technology Center

Morgantown, West Virginia

By

University of Wyoming Western Research Institute Laramie, Wyoming 


\section{DISCLAIMER}

This report was prepared as an account of work sponsored by an agency of the United States Government. Neither the United States Government nor any agency thereof, nor any of their employees makes any warranty, express or implied, or assumes any legal liability or responsibility for the accuracy, completeness or usefulness of any information, apparatus, product, or process disclosed, or represents that its use would not infringe privately owned rights. Reference herein to any specific commercial product, process, or service by trade name, trademark, manufacturer, or otherwise, does not necessarily constitute or imply its endorsement, recommendation, or favoring by the United States Government or any agency thereof. The views and opinions of authors expressed herein do not necessarily state or reflect those of the United States Government or any agency thereof.

This report has been reproduced directly from the best available copy.

Available to DOE and DOE contractors from the Office of Scientific and Technical Information, P.O. Box 62, Oak Ridge, TN 37831; prices available from (615)576-840i, FTS 626-8401.

Available to the public from the National Technical Information Service, U.S. Department of Commerce, 5285 Port Royal Rd., Springfield, VA 22161. 
Adsorption of Aniline and Toluidines on

Montmorillonite: Implications for the Disposal of Shale Oil Production Wastes

Topical Report

M.E. Essington

J.M. Bowen

R.A. Wills

B.K. Hart

Work Performed Under Contract No.: DE-FC21-86MC11076

\author{
For \\ U.S. Department of Energy \\ Office of Fossil Energy \\ Morgantown Energy Technology Center \\ P.O. Box 880 \\ Morgantown, West Virginia 26507-0880 \\ By \\ University of Wyoming \\ Western Research Institute \\ P.O. Box 3395 \\ University Station \\ Laramie, Wyoming 82071
}

January 1992 
LIST OF TABLES AND FIGURES .......................... iii

ABSTRACT $\ldots \ldots \ldots \ldots \ldots \ldots \ldots \ldots \ldots \ldots \ldots \ldots \ldots \ldots \ldots \ldots \ldots \ldots \ldots \ldots \ldots \ldots$

INTRODUCTION.................................... 1

MATERIALS AND METHODS ...............................

Preparation of Montmorillonite suspension................ 1

Adsorption studies............................... 2

Infrared Analysis............................... 3

REsuLts $\ldots \ldots \ldots \ldots \ldots \ldots \ldots \ldots \ldots \ldots \ldots \ldots \ldots \ldots \ldots \ldots \ldots \ldots \ldots \ldots$

Equilibrium Adsorption........................... 4

Infrared Analysis................................ 4

DIscussron $\ldots \ldots \ldots \ldots \ldots \ldots \ldots \ldots \ldots \ldots \ldots \ldots \ldots \ldots \ldots \ldots \ldots \ldots \ldots \ldots \ldots \ldots$

conchusrons .................................... 12

ACKNOWLEDGEMENT .................................... 13

DISCLAIMER .................................... 13

REFERENCES $\ldots \ldots \ldots \ldots \ldots \ldots \ldots \ldots \ldots \ldots \ldots \ldots \ldots \ldots \ldots \ldots \ldots \ldots \ldots \ldots \ldots \ldots$ 
1. Liquid ATR FT-IR Analysis of Aniline, $\mathrm{cm}^{-1} \ldots \ldots \ldots \ldots \ldots . . . . .4$

2. Liquid ATR FT-IR Analysis of o-toluidine, $\mathrm{cm}^{-1} \ldots \ldots \ldots \ldots . . . . .9$

3. Liquid ATR FT-IR Analysis of m-toluidine, $\mathrm{cm}^{-1} \ldots \ldots . . . . . .9$

4. Predicted Free Molal (mole $\mathrm{kg}^{-1}$ ) Concentrations of Chemical Components in the Aniline Adsorption system...... 11

\section{LIST OF FIGURES}

\section{Figure}

1. Adsorption of An:line on Bentonite as a Function of Saturating Cation, $\mathrm{pH}$, and Ionic Environment.............

2. Adsorption of o-toluidine on Bentonite as a Function of Saturating Cation, $\mathrm{pH}$, and Ionic Environment............

3. Adsorption of m-toluidine on Bentonite as a Function of Saturating Cation, $\mathrm{pH}$, and Ionic Environment.............

4. Adsorption of p-toluidine on Bentonite as a Function of Saturating Cation, $\mathrm{pH}$, and Ionic Environment............. 


\section{ABSTRACT}

Bentonite clay liners are commonly employed to mitigate the movement of contaminants from waste disposal sites. Solid and liquid waste materials that arise from the production of shale oil contain a vast array of organic compounds. Common among these compounds are the aromatic amines. In order to assess the ability of clay liner material to restrict organic compound mobility, the adsorption of aniline and o-, $\mathrm{m}-$, and p-toluidine on $\mathrm{Ca}^{2+}$ - and $\mathrm{K}^{+}$-saturated Wyoming bentonite (SWy-1) was investigated. Adsorption experiments were performed under conditions of varied $\mathrm{pH}$, ionic strength, and dominate electrolyte cation and anion. Organic adsorption on $\mathrm{Ca}^{2+}$ - and $\mathrm{K}^{+}$-saturated montmorillonite is pH dependent, with maximum adsorption occurring when pH is approximately equal to the $\mathrm{pk}_{\mathrm{a}}$ of the anilinium ion deprotonation reaction ( $\mathrm{pH} 4.45$ to 5.08 ). For any given organic compound, maximum adsorption increases with decreasing ionic strength. Organic compound adsorption is inhibited in the presence of sulfate and is greater in the $\mathrm{Ca}^{2+}$ systems than in the $\mathrm{K}^{+}$systems at any given ionic strength. High salt content and $\mathrm{K}^{+}$collapse the bentonite layers and limit access to and compete for adsorption sites. The $\mathrm{K}^{+}$ion is also more difficult to displace than $\mathrm{Ca}^{2+}$ from interlayer positions. Fourier transform infrared spectroscopic data show that the aniline compounds are adsorbed on bentonite through the hydrogen bonding of an amine hydrogen to a surface silica oxygen. Sulfate reduces amine adsorption by removing positively charged anilinium species from solution to form negatively charge sulfate complexes. Although adsorption of the substituted amines on bentonite is observed, aniline and toluidine adsorption is minimal in saline systems and not detected in alkaline systems. Thus, in shale oil process waste disposal sites, the mobility of the anilines through bentonite liners will not be mitigated by sorption processes, as spent oil shale leachates are both highly alkaline and saline. 


\section{INTRODUCTION}

spent oil shale and retort waters are the solid and liquid waste products that result from the production of synthetic crude oil from oil shale. These solid and liquid waste products contain a vast array of organic compounds (Pellizzari et al., 1979; stuermer et al., 1980; Leenheer et al., 1982; Poulson et al., 1985; Lane et al., 1986). Principal among these are the carboxylic acids, phenols, pyridine-type compounds, and the aromatic amines. The potential for spent oil shale to reduce the inorganic and organic chemical concentrations in retort waters during codisposal has been suggested (Fox et al., 1980; George and Jackson, 1985; Boardman et al., 1985). However, results from detailed adsorption studies with specific compound types have been mixed. Boardman et al. (1985) examined the adsorption of 2hydroxynaphthalene, $1,2,3,4$-tetrahydroguinoline, and 2,3,5triethylphenol by several spent Green River Formation oil shale samples. The reduction in organic compound solution concentrations ranged from 218 to greater than 968 , depending on the organic compound type. zhu et al. (1988) and Essington (1992) examined the adsorption of pyridine by spent Rundle oil shale, spent and weathered spent Green River Formation, and New Albany oil shale samples. They observed only a $10 \%$ reduction in organic compound solution concentrations.

Because spent oil shale may have a limited capacity to fix potentially hazardous organic compounds, the containment media used in disposal site construction must effectively restrict compound transport to off-site locations. Bentonite clay liners are commonly employed to prevent the percolation of leachates and the migration of potentially hazardous organic compounds from waste disposal sites by providing a physical barrier. In addition to providing a barrier to the physical movement of leachates and associated contaminants, clay liners can also serve as a sink for contaminants via adsorption processes.

The objectives of this study are to examine the ability of bentonite to attenuate the model aromatic amines: aniline, o-toluidine, mtoluidine, and p-toluidine. organic adsorption studies were performed as a function of solution $\mathrm{pH}$, saturating cation, background electrolyte, and ionic strength. The mechanisms responsible for aniline and toluidine adsorption were also examined using direct Fourier transform infrared spectroscopic analysis.

\section{MATERIALs AND METHODs}

\section{Preparation of Montmorillonite Suspension}

Wyoming bentonite (SWy-1) was obtained from the clay Mineral society source clays Repository. Calcium-saturated clay suspensions were prepared by placing $20.000 \mathrm{~g}$ of sWy-1 bentonite and approximately $1.5 \mathrm{~L}$ of $0.5 \mathrm{M} \mathrm{Ca}\left(\mathrm{C}_{2} \mathrm{H}_{3} \mathrm{O}_{2}\right)_{2}$ in a blender. The clay was suspended and the suspension $\mathrm{pH}$ was adjusted to approximately $\mathrm{pH} 4$ using $0.1 \mathrm{M} \mathrm{HCl}$ while operating the blender at low speed. The suspension was mixed for an additional $15 \mathrm{~min}$ using the medium blender setting. The clay suspension was quantitatively transferred to $1 \mathrm{~L}$ polypropylene centrifuge bottles 
using $0.5 \mathrm{M} \mathrm{Ca}\left(\mathrm{C}_{2} \mathrm{H}_{3} \mathrm{O}_{2}\right)_{2}$ to facilitate the transfer. The bottles were centrifuged at $1140 \mathrm{~g}$ (maximum radius) to obtain a clear supernatant liquid. The supernatant solution was decanted and discarded, and replaced with approximately $0.6 \mathrm{~L}$ of $0.5 \mathrm{M} \mathrm{Ca}\left(\mathrm{C}_{2} \mathrm{H}_{3} \mathrm{O}_{2}\right)_{2}$. The centrifuge bottles were tightly sealed, vigorously shaken to disperse the clay, and centrifuged to obtain a clear supernatant solution. The supernatant was decanted and discarded, and the $0.5 \mathrm{M} \mathrm{Ca}\left(\mathrm{C}_{2} \mathrm{H}_{3} \mathrm{O}_{2}\right)_{2}$ washings repeated two additional times. Following the $\mathrm{Ca}\left(\mathrm{C}_{2} \mathrm{H}_{3} \mathrm{O}_{2}\right)_{2}$ washings, the clay was washed twice with type I water and three times with either $0.01 \mathrm{M} \mathrm{CaCl}_{2}$, $0.1 \mathrm{MCaCl}_{2}$, or $0.005 \mathrm{MCaSO}$. The Ca'+saturated clay was quantitatively transferred to a 2 L volumetric flask and brought to volume with the background $\mathrm{ca}$ electrolyte. The suspensions were transferred to polypropylene bottles for storage. The weight of clay per unit volume of suspension was determined by drying known volumes of the suspensions at $115^{\circ} \mathrm{C}$ for $24 \mathrm{hr}$ and applying appropriate corrections for occluded salts. Over the course of the study, the suspensions contained between 9.99 and $10.04 \mathrm{mg} \mathrm{mL}^{-1}$ of clay.

The $\mathrm{K}^{+}$-saturated $\mathrm{sWy}-1$ bentonite was prepared in a manner similar to that described for $\mathrm{Ca}^{2+}$ saturation. However, $1 \mathrm{M} \mathrm{KCl}$ was used to $\mathrm{K}^{+}$ saturate the bentonite, and the final washings were performed using either $0.03 \mathrm{M} \mathrm{KCl}, 0.3 \mathrm{M} \mathrm{KCl}, 0.01 \mathrm{M} \mathrm{K}_{2} \mathrm{SO}_{4}, 0.05 \mathrm{M} \mathrm{K}_{2} \mathrm{SO}_{4}$, or $0.1 \mathrm{M} \mathrm{K}_{2} \mathrm{SO}_{4}$.

\section{Adsorption studies}

Aniline $\left(\mathrm{pK}_{\mathrm{a}}=4.63\right)$, o-toluidine $\left(\mathrm{pK}_{\mathrm{a}}=4.44\right), \mathrm{m}$-toluidine $(\mathrm{pK}=$ 4.73), and $\mathrm{p}$-toluidine ( $\left.\mathrm{pK}_{\mathrm{a}}=5.08\right)$ adsorption experiments were conducted in both the $\mathrm{Ca}^{2+}$ - and $\mathrm{K}^{+}$-saturated bentonite systems. The background electrolytes used in the $\mathrm{Ca}^{2+}$-saturated bentonite adsorption experiments were $0.01 \mathrm{M}$ and $0.1 \mathrm{M} \mathrm{CaCl} 2$ ( $I=0.03 \mathrm{M}$ and $0.3 \mathrm{M}$, respectively), and $0.005 \mathrm{M} \mathrm{CasO}_{4}(I=0.02)$. The background electrolytes used in the $\mathrm{K}^{+}$-saturated bentonite adsorption experiments were $0.03 \mathrm{M}$ and $0.3 \mathrm{M} \mathrm{KCl}$ ( $I=0.03 \mathrm{M}$ and $0.3 \mathrm{M}$, respectively), and 0.01 $M, 0.05 \mathrm{M}$, and $0.1 \mathrm{M} \mathrm{K}_{2} \mathrm{SO}_{4}(I=0.03 \mathrm{M}, 0.15 \mathrm{M}$, and $0.3 \mathrm{M}$, respectively).

Analytical grade aniline (99.5+8), o-toluidine $(99+8)$, m-toluidine (998), and p-toluidine (99.98) were obtained from Aldrich Chemical Co. and used without further purification. stock solutions containing 2000 $\mathrm{mg} \mathrm{L}^{-1}\left(21.48 \mathrm{mmol} \mathrm{L}^{-1}\right.$ aniline and $18.67 \mathrm{mmol} \mathrm{L}^{-1}$ toluidine) of each organic compound were prepared in the appropriate $\mathrm{Ca}^{2+}$ or $\mathrm{K}^{+}$background electrolyte solutions.

Adsorption experiments were performed by placing $20 \mathrm{~mL}$ of the clay suspension, $25 \mathrm{~mL}$ of an aniline or toluidine solution, and $5 \mathrm{~mL}$ of a $\mathrm{pH}$ adjusting solution in $50 \mathrm{~mL}$ Corex centrifuge tubes. The pH adjusting solutions were composed of the background electrolyte and $0.2 \mathrm{M} \mathrm{HCl}$ or $\mathrm{H}_{2} \mathrm{SO}_{4}$ that ranged in composition from 1008 background electrolyte to a 1:1 mixture. The centrifuge tubes were sealed with Teflon-lined screw caps, wrapped in aluminum foil, and equilibrated on a wrist-action shaker for $24 \mathrm{hr}$ at ambient temperatures $\left(20-25^{\circ} \mathrm{C}\right)$. The adsorption experiments, including blanks, were run in triplicate. preliminary adsorption experiments showed that a 4-hr equilibration period was 
adequate for the completion of aniline and toluidine adsorption reactions. These experiments also showed that the adsorption equilibrium was stable up to 48 hours and that no adsorption of the organic compounds occurred on the corex centrifuge tubes.

Following the equilibration period, the adsorption systems were centrifuged at $1140 \mathrm{~g}$ (maximum radius) to obtain clear supernatant solutions. A $10-\mathrm{mL}$ aliquot was extracted from each centrifuge tube and placed in a $100-\mathrm{mL}$ volumetric flask. A $10-\mathrm{mL}$ aliguot of $0.1 \mathrm{M} \mathrm{Ca}(\mathrm{OH})_{2}$ or $\mathrm{KOH}$ was added to each flask, which was brought to volume with the appropriate background electrolyte. The solutions were analyzed for aniline or the toluidines by UV spectrophotometry (Shimadzu UV-265 spectrophotometer, Shimadzu Corp., Kyoto, Japan) at a wavelength of approximately $280 \mathrm{~nm}$.

Equilibrium supernatant solution pH was determined using a standardized ( $\mathrm{pH} 4$ and 7 ) combination $\mathrm{pH}$ electrode (Corning science products, Corning, NY) and a sargent-Welch MPT automatic titrator microprocessor (Sargent-Welch Scientific Co., Skokie, IL). Standard solutions for UV analysis ranged in concentration from $10 \mathrm{mg} \mathrm{L}^{-1}$ to 120 $\mathrm{mg} \mathrm{L}^{-1}$ and were prepared by placing varied volumes of organic compound stock solutions and $10-\mathrm{mL}$ aliquots of $0.1 \mathrm{M} \mathrm{Ca(OH})_{2}$ or $\mathrm{KOH}$ into $100-\mathrm{mL}$ volumetric flasks, which were brought to volume with the appropriate background electrolyte. The coefficient of determination $\left(r^{2}\right)$ for each standard curve always exceeded 0.999. The total amount of aniline or o-, $\mathrm{m}-$, or p-toluidine adsorbed by $\mathrm{sWy}-1$ bentonite was calculated from the difference between organic compound concentrations in the initial and the equilibrium solutions.

\section{Infrared Analysis}

Liquid attenuated total reflectance (ATR) Fourier transform infrared (FT-IR) spectroscopic analysis was used to study the mechanism of aniline and toluidine adsorption by bentonite. Calcium- and $\mathrm{K}^{+}-$ saturated bentonite samples were retained from the $\mathrm{pH} 2, \mathrm{pH} 4$, and $\mathrm{pH}$ 6.5 organic sorption studies for liquid ATR FT-IR analysis. Following certerifugation and the removal of the equilibrium solutions, a subsample of the remaining organo-bentonite slurry was smeared on the surface of a germanium rhomb. The rhomb was placed in the liquid ATR cell (Buck Scientific) and the FT-IR spectra acquired using a BioRad-Digilab FTS-45 Fourier transform infrared spectrometer. Infrared spectra of bentonite slurries and spectra of the pure organic compounds were similarly obtained. The spectra obtained for the organo-bentonite slurries were subtracted from spectra of the bentonite slurries (at the appropriate pH and ionic environment) to obtain difference spectra. The difference spectra were analyzed to identify peak shifts in the $\mathrm{N}-\mathrm{H}$ stretch bands of sorbed organics by comparing the difference spectra to spectra of the pure organic compounds. 


\section{RESULTS}

\section{Equilibriun Adsorption}

The maximum amount of aniline and the toluidines adsorbed on bentonite is $\mathrm{pH}$ dependent. Above $\mathrm{pH} 7$, organic compound adsorption was not detected. Adsorption increases as $\mathrm{pH}$ decreases from approximately $\mathrm{pH} 7$, with the adsorption maximum $\left(\mathrm{X} / \mathrm{M}_{\max }\right)$ occurring when solution $\mathrm{pH}$ is approximately equal to the $\mathrm{pK}_{\mathrm{a}}$ of the anilinium ion deprotonation reaction: $\mathrm{R}-\mathrm{NH}_{3}^{+}=\mathrm{R}-\mathrm{NH}_{2}^{0}+\mathrm{H}^{+}$(Figures 1 through 4 ). As solution $\mathrm{pH}$ is reduced below the $\mathrm{pK}_{\mathrm{a}}$, adsorption decreases.

The amount of aniline or toluidine adsorbed at $\mathrm{x} / \mathrm{M}_{\mathrm{max}}$ is influenced by the dominant electrolyte cation, saturating cation, and the ionic medium. Aniline and m-toluidine adsorption (Figures 1 and 3 ) is greatest in the Ca systems and the low ionic strength $(0.03 \mathrm{M}) \mathrm{KCl}$ system. Adsorption was lowest in the $\mathrm{K}_{2} \mathrm{SO}_{4}$ and the high ionic strength $(0.3 \mathrm{M}) \mathrm{KCl}$ systems. For o-toluidine (Figure 2 ), adsorption is greatest in the low ionic strength $\mathrm{Ca}$ and $\mathrm{KCl}$ systems. For p-toluidine (Figure $4)$, adsorption was greatest in the low ionic strength $(0.02-0.03 \mathrm{M})$ systems, irrespective of background electrolyte.

\section{Infrared Analysis}

Analysis of the organo-bentonite adsorption interactions was performed at three different solution $\mathrm{pH}$ values using the liquid ATR FTIR cell. This method allows for the determination of organic adsorption mechanisms in aqueous suspensions as a function of the chemical properties of the solution phase. Large negative shifts in $v_{\mathrm{g}}(\mathrm{NH})$ and $V_{\mathrm{a}}(\mathrm{NH})$ for aniline, o-toluidine, and m-toluidine in both $\mathrm{pH} 4$ and $\mathrm{pH} 6.5$ systems, independent of dominate electrolyte cation, were observed (Tables 1, 2, and 3 ). The band shifts are greatest in the pH 4 systems. Further, $v_{g}(\mathrm{NH})$ and $v_{a}(\mathrm{NH})$ bands were not observed for p-toluidine or for the $p H 2$ systems. The large negative shift in $v_{s}(N H)$ and $V_{a}(N H)$ suggests that an amine hydrogen is hydrogen bonded to a surface silica oxygen.

Table 1. Liquid ATR FT-IR Analysis of Aniline, $\mathrm{cm}^{-1}$

\begin{tabular}{|c|c|c|c|c|c|}
\hline \multirow{3}{*}{$\frac{\text { Assignment }}{v_{\mathbf{s}}(\mathrm{NH})}$} & \multirow{3}{*}{$\frac{\text { Pure }}{3432}$} & \multicolumn{2}{|c|}{$\mathrm{pH} \quad 4$} & \multicolumn{2}{|c|}{$\mathrm{pH} 6.5$} \\
\hline & & $\mathrm{Ca}^{2+}$ & $\mathrm{K}^{+}$ & $\mathrm{Ca}^{2+}$ & $\mathrm{K}^{+}$ \\
\hline & & $3395(-37)^{a}$ & $3393(-39)$ & $3399(-33)$ & $3399(-33)$ \\
\hline & 3433 & $3395(-38)$ & -- & $3401(-32)$ & -- \\
\hline \multirow[t]{2}{*}{$v_{\mathbf{a}}(\mathrm{NH})$} & 3354 & $3314(-40)$ & $3314(-40)$ & $3329(-25)$ & $3336(-18)$ \\
\hline & 3353 & $3314(-39)$ & -- & $3329(-24)$ & -- \\
\hline
\end{tabular}

a Number in parentheses denotes shift 


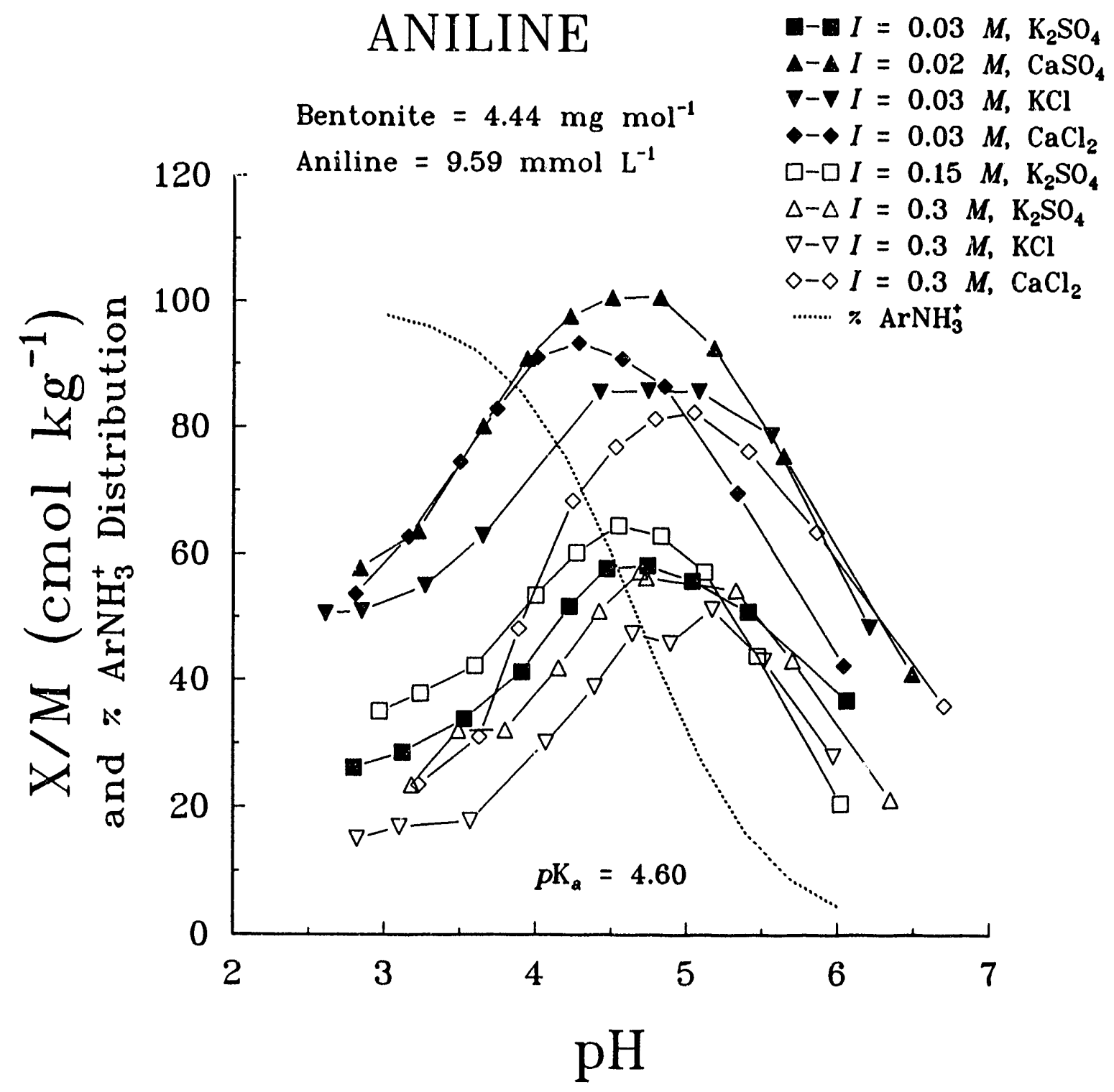

Figure 1. Adsorption of Aniline on Bentonite as a Function of saturating Cation, $\mathrm{PH}$, and Ionic Environment 


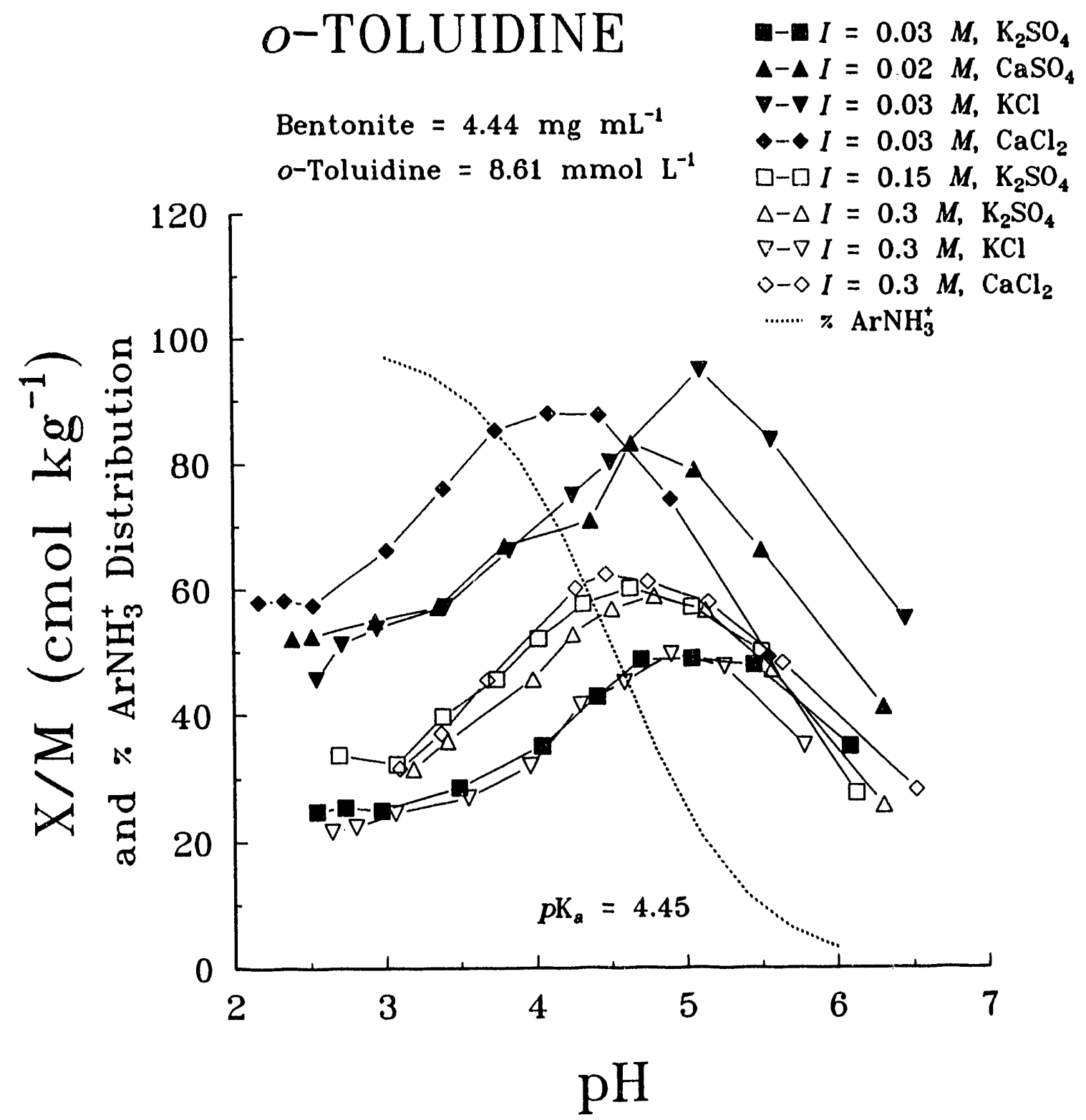

Figure 2. Adsorption of o-toluidine on Bentonite as a Function of saturating Cation, $\mathbf{p H}$, and Ionic Environment 


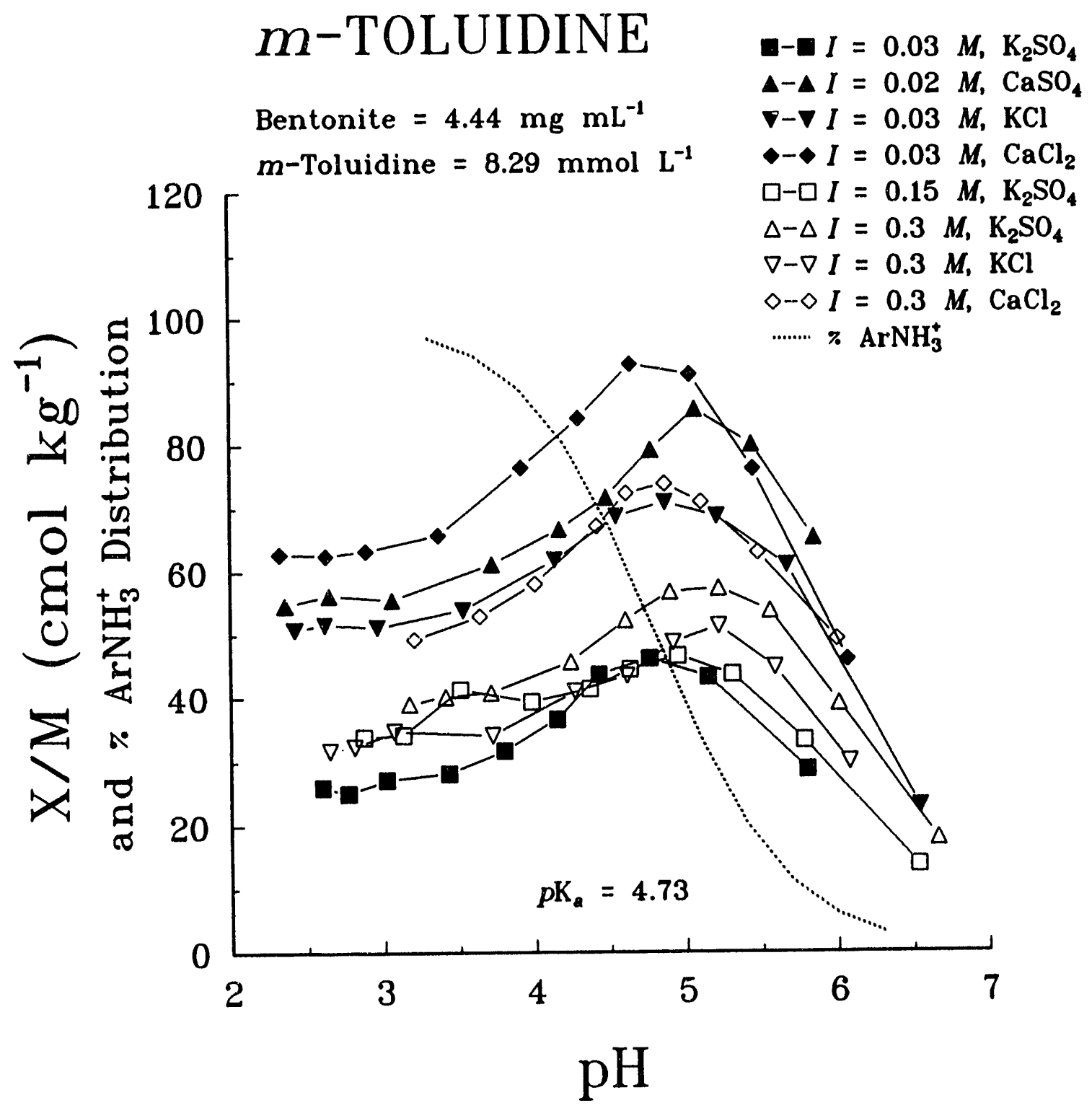

Figure 3. Adsorption of -toluidine on Bentonite as a Function of saturating Cation, $\mathrm{pH}$, and Ionic Enviromnent 


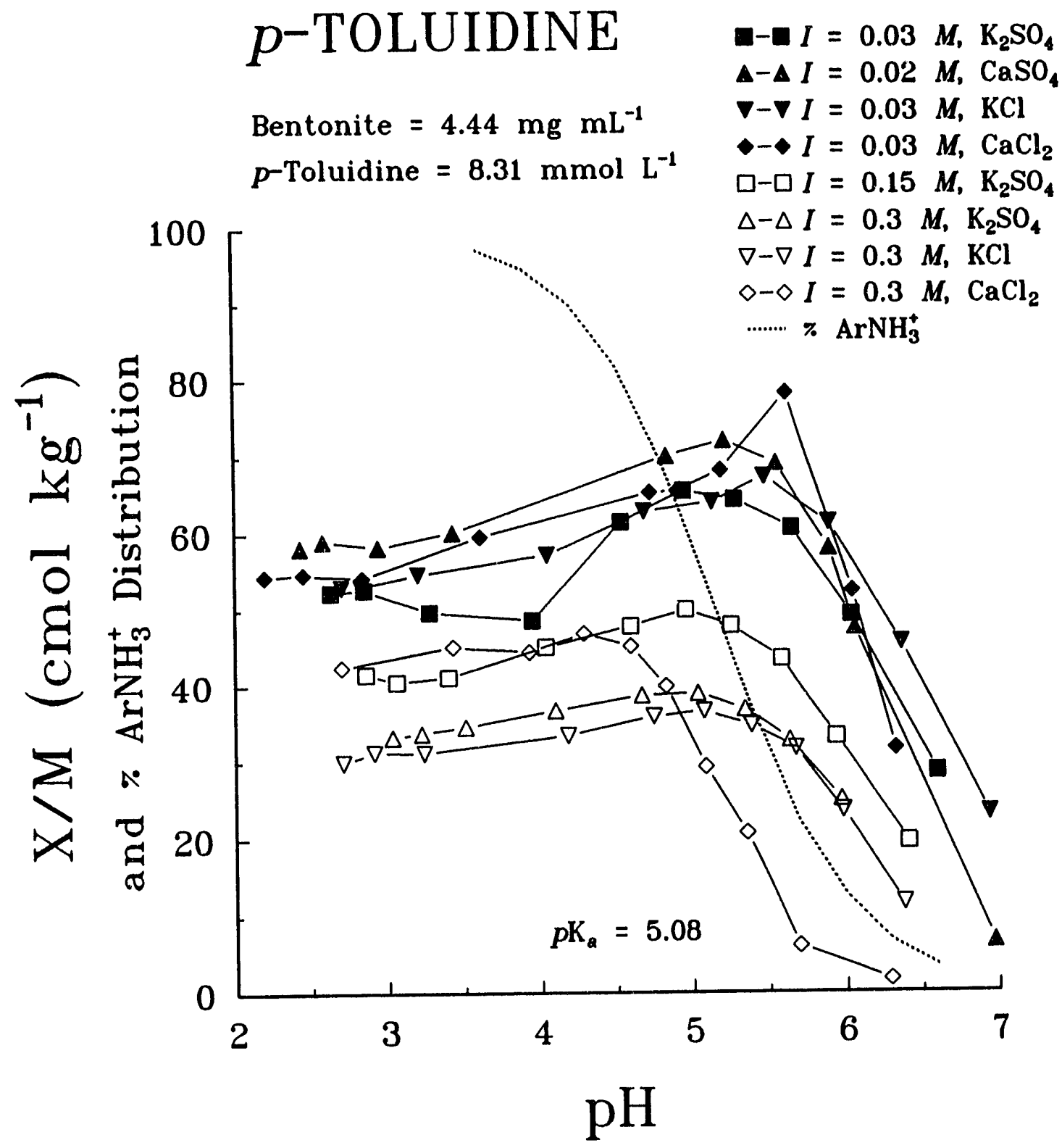

Figure 4. Adsorption of p-toluidine on Bentonite as a Function of saturating Cation, pH, and Ionic Environment 
Table 2. Liquid ATR FT-IR Analysis of o-toluidine, $\mathrm{cm}^{-1}$

\begin{tabular}{|c|c|c|c|c|c|}
\hline \multirow[b]{2}{*}{ Assignment } & \multirow[b]{2}{*}{ Pure } & \multicolumn{2}{|c|}{$\mathrm{pH} 4$} & \multicolumn{2}{|c|}{$\mathrm{pH} \quad 6.5$} \\
\hline & & $\mathrm{Ca}^{2+}$ & $\mathrm{K}^{+}$ & $\mathrm{Ca}^{2+}$ & $\mathbf{K}^{+}$ \\
\hline \multirow{2}{*}{$v_{a}(\mathrm{NH})$} & 3455 & $3393(-62)^{a}$ & -- & $3401(-54)$ & - \\
\hline & 3452 & - & $3382(-70)$ & -- & $3390(-62)$ \\
\hline \multirow[t]{2}{*}{$V_{a}(N B)$} & 3367 & $3318(-49)$ & --1 & $3325(-42)$ & -- \\
\hline & 3362 & -- & $3311(-51)$ & - & $3325(-37)$ \\
\hline
\end{tabular}

a Number in parentheses denotes shift

Table 3. Liquid ATR FT-IR Analysis of m-toluidine, $\mathrm{cm}^{-1}$

\begin{tabular}{|c|c|c|c|c|c|}
\hline \multirow[b]{2}{*}{ Assignment } & \multirow[b]{2}{*}{ Pure } & \multicolumn{2}{|c|}{$\mathrm{pH} 4$} & \multicolumn{2}{|c|}{$\mathrm{pH} 6.5$} \\
\hline & & $\mathrm{Ca}^{2+}$ & $\mathbf{K}^{+}$ & $\mathrm{Ca}^{2+}$ & $\mathrm{K}^{+}$ \\
\hline \multirow{4}{*}{$v_{s}(\mathrm{NH})$} & 3432 & $3391(-41)^{a}$ & -- & $3395(-37)$ & -- \\
\hline & 3430 & $3391(-39)$ & -- & $3395(-35)$ & -- \\
\hline & 3436 & -- & $3389(-47)$ & -- & $3402(-34)$ \\
\hline & 3430 & -- & $3390(-40)$ & -- & $3391(-39)$ \\
\hline \multirow[t]{4}{*}{$v_{a}(N H)$} & 3350 & $3311(-39)$ & -- & $3323(-27)$ & -- \\
\hline & 3350 & $3311(-39)$ & - & $3321(-29)$ & - \\
\hline & 3350 & -- & $3312(-38)$ & -- & $3335(-15)$ \\
\hline & 3350 & -- & $3310(-40)$ & -- & $3321(-29)$ \\
\hline
\end{tabular}

a Number in parentheses denotes shift

\section{DIscussion}

As $\mathrm{pH}$ decreases from a value of 7 , aniline and toluidine adsorption increases to a maximum when solution pH is approximately equal to the $\mathrm{pk}_{\mathrm{a}}$ of the anilinium ion deprotonation reaction. This increase in adsorption is due to the increasing proportion of aniline or toluidine present as the positively charged anilinium species (Figures 1 through 4). Adsorption decreases from $X / M_{\max }$ with an additional decrease in $\mathrm{pH}$. This may be due to competition with $\mathrm{H}^{+}$. In general, the amount of organic adsorbed was greatest in the $\mathrm{Ca}^{2+}$ and low ionic strength systems, compared to that observed in the $\mathrm{K}^{+}$and $\mathrm{high}$ ionic strength 
systems. These results are consistent with those obtained by zachara et al. (1984). They examined aniline adsorption by soil and observed a decrease in aniline adsorption with increasing ionic strength. They also found the aniline adsorption maximum to occur when solution pH was approximately equal to the $\mathrm{pK}_{\mathrm{a}}$.

High ionic strength solutions and the $\mathrm{K}^{+}$ion promote the collapse of the bentonite layers, and limit the access of anilines to adsorption sites. Increasing $\mathrm{Ca}^{2+}$ and $\mathrm{K}^{+}$concentrations also result in increased competition with the anilinium ion for adsorption sites. Further, $\mathrm{Ca}^{2+}$, due to its high negative hydration energy in comparison to $\mathrm{K}^{+}$, maintains a larger hydrated ionic radius when reacting with interlayer surfaces. Thus, in relation to $\mathrm{K}^{+}, \mathrm{Ca}^{2+}$ may be more easily displaced from the bentonite surface by the protonated amines. These results conflict with those of Moreale and Van Bladel (1979). They examined aniline adsorption by $\mathrm{K}^{+}$- and $\mathrm{Ca}^{2+}$-saturated Camp-Berteau montmorillonite and found greater aniline adsorption in the $\mathrm{K}^{+}$system. However, solution $\mathrm{pH}$, dominant electrolyte cation and anion, and ionic strength were not defined by Moreale and Van Bladel (1979). Thus, their adsorption results can not be directly compared to those obtained here.

The adsorption and FT-IR data also suggest that aniline and toluidine adsorption is strongly dependent on the free solution concentrations of the protonated amines. Spectroscopic data suggest that the adsorption of aniline and toluidine proceeds through an innersphere complexation reaction were a hydrogen on the protonated amine is directly bonded to a surface si-o group. Thus, aqueous speciation reactions that compete for the protonated amine will reduce adsorption. Ion pair formation with sulfate reduces aniline and toluidine adsorption through the formation of a negatively charged complex, such as $\left[\mathrm{C}_{6} \mathrm{H}_{6} \mathrm{NH}_{3}-\right.$ $\mathrm{SO}_{4} \mathrm{~J}^{-}$. Greater amine adsorption in the $\mathrm{CaSO}_{4}$ systems, compared with that in the $\mathrm{K}_{2} \mathrm{SO}_{4}$ systems, is due to the formation of the Casolion pair. The formation of $\mathrm{CaSO}_{4}^{0}$ removes $\mathrm{SO}_{4}^{2-}$ from solution, leaving less free $\mathrm{SO}_{4}^{2-}$ to complex with the anilines.

Although association constants for the formation of $\left[\mathrm{C}_{6} \mathrm{H}_{6} \mathrm{NH}_{3}-\mathrm{SO}_{4}\right]^{-}$ and $\left[\mathrm{CH}_{3} \mathrm{C}_{6} \mathrm{H}_{6} \mathrm{NH}_{3}-\mathrm{SO}_{4}\right]^{-}$ion pairs are not available, insight into the aqueous chemistry of the aniline adsorption systems can be obtained by comparison to a system containing $\mathrm{NH}_{4}^{+}$and $\mathrm{SO}_{4}^{2-}$. In such a model, the formation of $\left[\mathrm{NH}_{4} \mathrm{SO}_{4}\right]^{-}$can be predicted ( $\log \mathrm{K}_{\mathrm{f}}$ known). The results of such an analysis, performed using the PHREEQE code (Parkhurst et al., 1980 ), are shown in Table 4. Although the $\left[\mathrm{NH}_{4} \mathrm{SO}_{4}\right]^{-}$complex only accounts for a small percentage of the total amine present in the system $\left(\log \mathrm{K}_{\mathrm{f}}=1.11\right)$, the model results suggest the removal of protonated amine from solution through the formation of the negatively charged sulfate complex. Clearly, for ion pair formation to significantly influence aniline adsorption, the $\log \mathrm{K}_{\mathrm{f}}$ values for $\left[\mathrm{C}_{6} \mathrm{H}_{6} \mathrm{NH}_{3}-\mathrm{SO}_{4}\right]^{-}$and $\left[\mathrm{CH}_{3} \mathrm{C}_{6} \mathrm{H}_{6} \mathrm{NH}_{3}-\mathrm{SO}_{4}\right]^{-}$formation must be significantly greater than that for $\left[\mathrm{NH}_{4} \mathrm{SO}_{4}\right]^{-}$formation. 


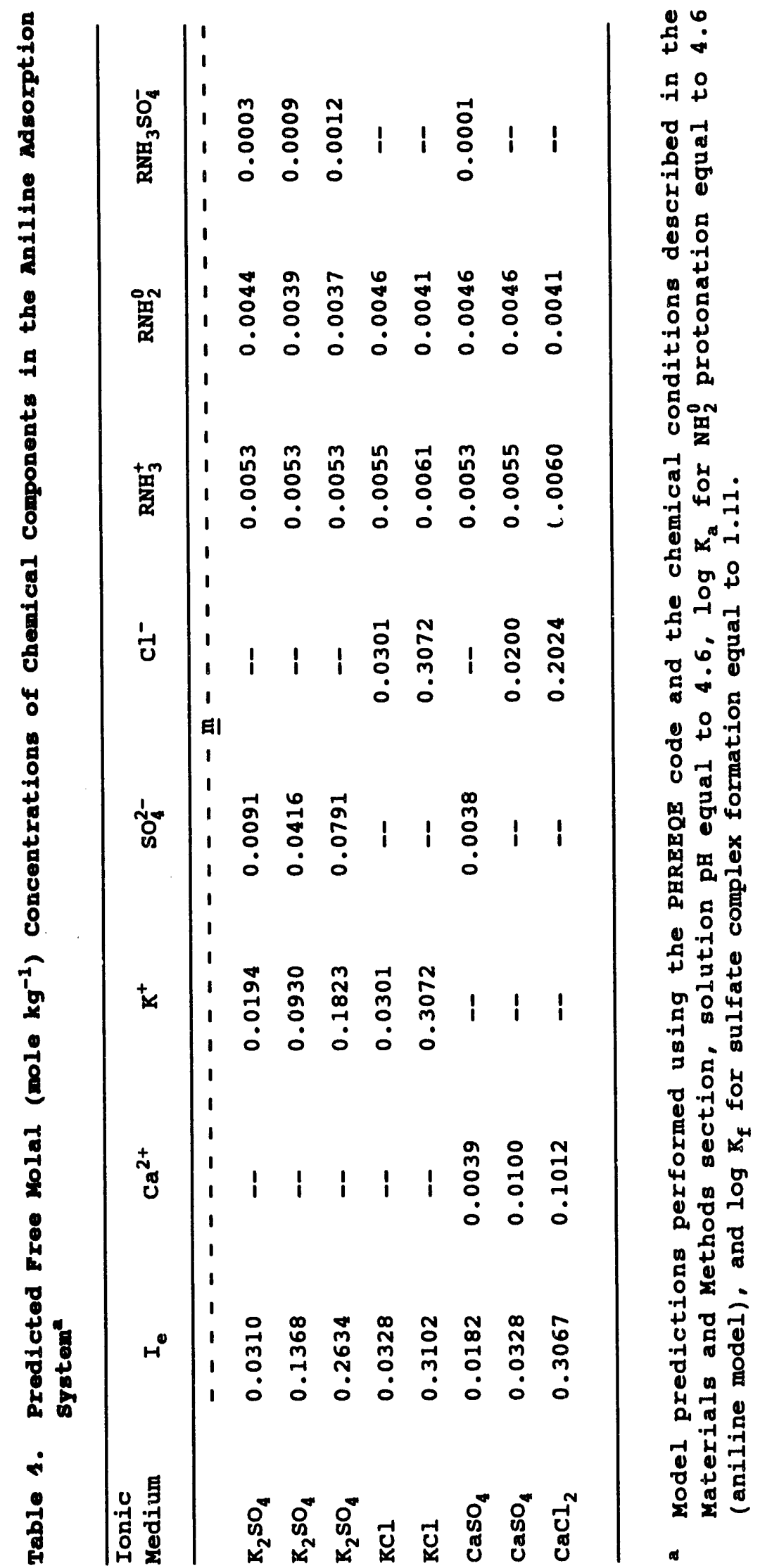




\section{CONCLUSIOKS}

Organic adsorption on $\mathrm{Ca}^{2+}$ - and $\mathrm{K}^{+}$-saturated montmorillonite is $\mathrm{pH}$ dependent, with maximum adsorption occurring when $\mathrm{pH}$ is approximately equal to the $\mathrm{pk}_{\mathrm{a}}$ of the anilinium ion deprotonation reaction ( $\mathrm{pH} 4.45$ to 5.08). For any given organic compound, maximum adsorption increases with decreasing ionic strength. Organic compound adsorption is inhibited in the presence of sulfate and is greater in the Ca ${ }^{2+}$ systems than in the $\mathrm{K}^{+}$systems at any given ionic strength. High salt content and $\mathrm{K}^{+}$collapse the bentonite layers and limit access to adsorption sites. Increasing the $\mathrm{Ca}^{2+}$ and $\mathrm{K}^{+}$ion concentrations also provides greater competition with the amines for adsorption sites. Further, the $\mathrm{K}^{+}$ion is more difficult to displace than Ca ${ }^{2+}$ from interlayer positions. Spectroscopic data show that the aniline compounds are adsorbed on bentonite through the direct bonding of an amine hydrogen to a surface silica oxygen. Sulfate reduces aniline adsorption by removing protonated and positively charged amine species from solution to form negatively charged sulfate complexes.

Although adsorption of the substituted amines on bentonite is observed, aniline and toluidine adsorption is minimal in high ionic strength saline systems and not detected in alkaline (greater than pH 7) systems. Commonly, spent oil shale leachates and retort waters are both highly alkaline and saline. Thus, in shale oil process waste disposal sites, the mobility of the anilines through bentonite liners may not be mitigated by sorption processes. 


\section{ACKMOWLEDGEMENT}

The authors express appreciation to the United states Department of Energy for funding of this work under Cooperative Agreement Number DEFC21-86MC11076.

\section{DISCLAIMER}

Mention of specific brand names or models of equipment is for information only and does not imply endorsement of any particular brand. 


\section{REFERENCES}

Boardman, G.D., A.N. Godrej, D.M. Cowher, and Y.W. Lu, 1985, The sorption-desorption capacity of oil shale materials. U.S. Department of Energy Report, DOE/LC/10964-2037, National Technical Information service, springfield, VA.

Essington, M.E, 1992, Adsorption of pyridine by combusted oil shale. Environ. Geol. Water Sci., in press.

Fox, J.P., D.E. Jackson, and R.H. Sakaji, 1980, Potential uses of spent oil shale in the treatment of oil shale retort waters. In J.H. Gary, ed., 13 th oil shale symposium Proceedings, April 1980. Colorado School of Mines, Golden, Co, p. 311-320.

George, M., and L. Jackson, 1985, Leach potential of codisposed spent oil shale and retort water using two extraction methods. U.S. Department of Energy Report, DOE/FE/60177-1882, National Technical Information service, springfield, VA.

Lane, D.C., K.J. Baughman, and J.S. Jones, 1986, Characterization of oil shale waters by gas chromatography/mass spectrometry. U.S. Department of Energy Report, DOE/FE/60177-2434, National Technical Information service, springfield, VA.

Leenheer, J.A., T.I. Noyes, and N.A. Stuber, 1982, Determination of polar organic solutes in oil-shale retort water. Environ. sci. Technol., 16: 714-723.

Moreale, A., and R. Van Bladel, 1979, Adsorption of herbicide-derived anilines in dilute aqueous montmorillonite suspensions. Clay Minerals, 14: 1-11.

Parkhurst, D.L., D.C. Thorstenson, and L.N. Plummer, 1980, PHREEQE - A computer program for geochemical calculations. Water Resources Investigations 80-96, U.S. Geological survey, Washington, DC.

Pellizzari, E.D., N.P. Castillo, S. Willis, D. Smith, and J.T.Bursey, 1979, Identification of organic components in aqueous effluents from energy-related processes. In C.E. VanHall, ed., Measurement of organic pollutants in water and wastewater, ASTM STP 686 , American Society for Testing and Materials, Philadelphia, PA, p. 256-274.

Poulson, R.E., J.A. Clark, and H.M. Borg, 1985, Organic solute profile of water from Rio Blanco Retort 1. U.S. Department of Energy Report, DOE/FE/60177-2366, National Technical Information Service, springfield, VA.

stuermer, D.H., D.J. Ng, C.J. Morris, and R.R. Treland, 1980, The identification of organic compounds in oil shale retort water by GC and GC-MS. In R.H. Filby et al., eds., Atomic and nuclear methods in fossil energy research. Plenum Press, New York, NY, p. 383-397. 
Zachara, J.M., L.J. Felice, and J.K. Sauer, 1984, sorption of aniline on selected Alfisols from the eastern coal region. Soil sci., 138: 209-219.

Zhu, S., P.R.F. Bell, and P.F. Greenfield, 1988, Adsorption of pyridine onto spent Rundle oil shale in dilute aqueous solution. Water Res., 22: 1331-1337. 

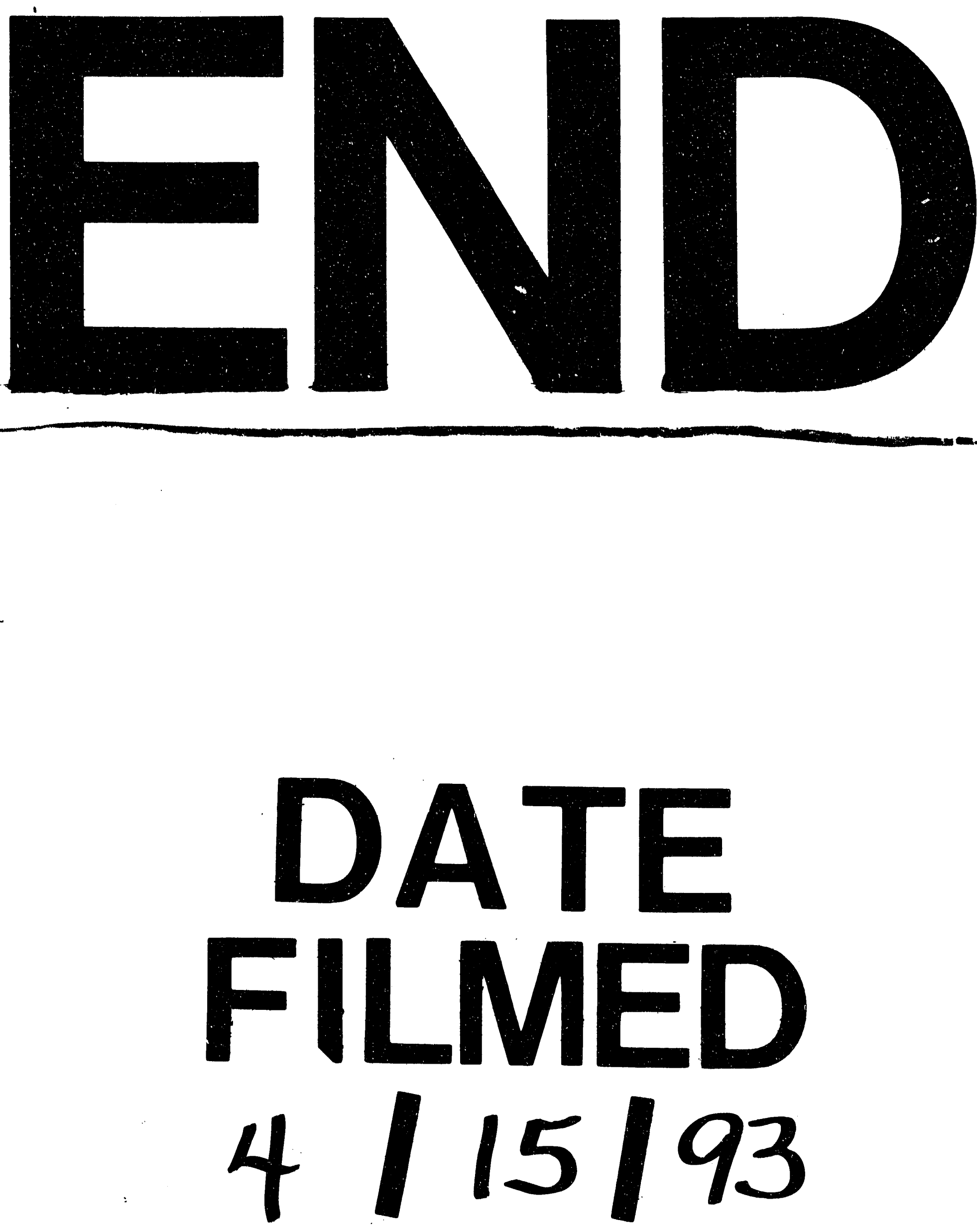
